\title{
Promoting Communicative Language Learning through Communicative Tasks
}

\author{
Ko-Yin Sung \\ Department of Languages, Philosophy \& Speech Communication, Utah State University, Logan, USA \\ Email: koyin.sung@usu.edu
}

\begin{abstract}
This study examines the level of effectiveness and suitability of three communicative language teaching-based projects in a particular teaching context, namely, a first-year Chinese language classroom in a university in Utah. Research data included participants' sample project work, project feedback forms, and focus-group interviews. The results showed that the participants spoke highly about the projects while they also made a couple suggestions for project modifications in order to better fit their individual learning needs. The findings suggest that, when designing communicative language teaching-based projects, learning about students' needs in a particular teaching context is a key to ensure project success.
\end{abstract}

Index Terms - communicative language teaching, communicative language learning, Chinese language

\section{INTRODUCTION}

Over 30 years ago theories and practices on second language teaching and learning shifted from being grammarbased to focusing of the communicative aspect of language learning (Leung, 2005). In explaining the process of second language acquisition, Chomsky (1965) created the concept of linguistic competence and performance. For Chomsky (1965), there can be no linguistics until a clear distinction is drawn between linguistic performance, which refers to people's speech actions, and linguistic competence, which is the knowledge of a language that makes those speech actions possible. Other researchers (Canale \& Swain, 1980; Hymes, 1987) in the field of second language acquisition see this concept of linguistic competence and performance as lacking the social and cultural component. Hence, researchers use of the term, communicative competence, emerged in the work of Hymes (1987) to help augment Chomsky's (1965) concept of linguistic competence and performance with the social component in second language learning.

\section{COMMUNiCATIVE COMPETENCE}

Communicative competence involves the social and cultural knowledge speakers are presumed to have which enables them to use and interpret the forms of a language (Saville-Troike, 2003). A speaker is said to have communicative competence if he or she knows what to say to whom and how to say it appropriately in any given situation (Schiffrin, 1994). Hymes (1987) claims that communicative competence is made up of four types of competencies. The first competence is linguistic competence referring to speakers' knowledge of grammatical structure in a language. The second competence is the knowledge of appropriateness, which is defined as sociolinguistic competence by Canale and Swain (1980). Speakers possessing sociolingusitic competence would produce utterances that are understood appropriately in different sociolinguistic contexts depending on factors such as purposes of the interaction, convention of the interaction, and background of participants (Leung, 2005). The third competence, discourse competence, concerned with cohesion and coherence, refers to the knowledge and skill required to combine grammatical forms and meanings to produce different types of spoken or written texts (Leung, 2005). The fourth competence, strategic competence, refers to strategies used to compensate for breakdowns in communication due to limiting conditions in actual communication or to enhance the effectiveness of communication. Speakers of a language need to acquire all four competences identified in communicative competence in order to speak and act appropriately in a speech community.

Saville-Troike (2003) gives a few examples of knowledge and skills communicatively competent speakers would possess. They are: knowledge of when to speak and when to remain silent, how one may talk to persons of different statuses and roles, what nonverbal behaviors are appropriate in various contexts, what the routines for turn-taking are in conversation, how to ask for and give information, how to request, and how to offer or decline assistance. In short, communicative competence is "everything involving the use of language and other communicative modalities in particular social settings" (Saville-Troike, 2003, p. 18).

\section{Communicative Language Teaching}

The communicative language teaching (CLT) approaches have become widely promoted in second language teaching since communicative competence, on which CLT is based, was introduced in the second language acquisition field (Li 
\& Hedebouw, 2009). According to Nunan (1988), "a basic principle underlying all communicative approaches is that learners must learn not only to make grammatically correct, propositional statements about the experiential world, but must also develop the ability to use language to get things done" (p. 25). In other words, the CLT approaches focus on the effectiveness of communication rather than the practice of grammatical patterns. Ma (2009) identifies a few typical communicative activities in CLT: group discussion, simulation, and role-play, all of which emphasize collaboration among peers in real or simulated real-life situations. In sum, CLT approaches advocate the idea that second language acquisition develops through communicative tasks, which are class activities that resemble real-world language tasks (Nunan, 1989).

Current literature on CLT touches upon CLT in relation to second language teaching and learning at different levels. The two most widely discussed aspects are the teaching context and the relationship between CLT beliefs and practices. First, there are debates among scholars on the teaching context in which CLT can be relevantly applied. This argument stems from Bax's (2003) and Holliday's (1994) claim that when teaching, language educators should take into account the context of the teaching environment and that it is risky to export a teaching approach such as CLT from one context to another. On the other side, Liao (2004) takes the view of what Larsen-Freeman (2000) called 'absolutism', advocating that CLT is the best approach. CLT applies in all teaching contexts including teaching in China, a nation which has distinctly different teaching and learning context from that of a western nation. Second, several studies on CLT focus on teachers' beliefs and teaching practices. Feryok (2008), who investigated the level of consistency between a language teacher's CLT beliefs and her teaching practice, reported that both the teacher's teaching beliefs and practices were influenced by her understanding of the teaching context in which she worked. For example, Feryok (2008) notes that the students expectation of the teacher as a facilitator reinforces that the teacher should recast answers more frequently. Feryok's (2008) study implies that both positive and negative situational factors in a teaching context could possibly influence CLT practices. Indeed, Liao (2003), the advocator of the use of CLT in China, states that the situational constraints found in particular teaching contexts can hinder the adoption of CLT practices. Nonetheless, Liao (2003) proclaims that language instructors can overcome these obstacles if they are aware of the constraints. Liao (2003) uses her study done in China as an example to support her claim. In Liao's (2003) case study of a secondary school teacher in China, the teacher, who reported holding favorable attitudes towards CLT, was able to successfully execute CLT practices even though she had several situational constraints including large class size and mandatory function-based textbook.

The review of the current literature on CLT shows that the teaching context is a crucial factor determining whether or not CLT can be successfully implemented in the classroom. Some researchers (Bax, 2003; Holliday, 1994; Hu, 2005) take the position that CLT is not equally suited to all contexts while others (Hiep, 2007; Liao, 2003; Liao, 2004) claim that issues which come up in a particular context do not necessarily negate the potential usefulness of CLT. I take the later view as my position. As a Chinese language instructor, I have been eager to develop effective CLT-based in- and after-class language tasks which are best suited to the particular teaching context in which I work. Hence, the aim of this paper is to investigate the effectiveness and suitability of newly designed CLT-based projects in the teaching context of a first-year Chinese language class in a Chinese minor program in a mid-size state university in Utah. In particular, this study attempts to answer the following research questions:

1. What are learners' linguistic gains in doing the CLT-based projects?

2. What are learners' reactions in doing the CLT-based projects?

3. What recommendations do learners make in improving the design of the projects in order to better fit the particular teaching and learning context?

In order to ensure that the projects I designed were indeed CLT-based tasks, I followed Nunan's (1989) framework for analyzing communicative tasks.

\section{COMMUNiCATIVE TASKS}

Communicative task is a key element in CLT; hence, what characteristics account for a communicative task needs to be discussed. Nunan (1989) defines communicative task as "a piece of classroom work which involves learners in comprehending, manipulating, producing or interacting in the target language while their attention is principally focused on meaning rather than form" (p. 10). Nunan (1989) stresses that it is not an easy task to draw a distinction between communicative and non-communicative tasks; therefore, he has created the framework for analyzing communicative tasks to systematically identify tasks which are considered having the communicative features. Nunan (1989) first points out that a language learning task consists of six components: goals, input, activities, teacher role, learner role and settings. Secondly, a communicative task has certain characteristics in each of the six components. Discussion of the six components of a communicative task follows:

Goals: Goals refer to the purposes of a language task. Goals for a communicative task include developing human relations through exchange of information, thoughts and feelings, and completing an action.

Input: Input is "the data that form the point of departure for the task" (Nunan, 1989, p. 53). The input data for a communicative task has the feature of being authentic, meaning the material has not been specifically produced for the purpose of language teaching and learning. Some examples of input used in a communicative task include but are not limited to hotel brochures, business cards, menu, and storybooks. 
Activities: Activities are what learners are expected to do with the input for the task. Three characteristics are emphasized for activities in a communicative task. First, the activities must be authentic in terms of reflecting realworld tasks. Second, the activities should stimulate learners to apply newly acquired linguistic knowledge to real communication. Finally, the activities are designed to help develop the accuracy and fluency of learners' target language.

Learner roles: In a communicative task, learners are seen as members of a community progressively moving from dependent to independent learners.

Teacher roles: The teacher working with learners in a communicative task has three main roles, which are facilitator, participant, and observer.

Settings: Settings are comprised of the learning mode (e.g. task for whole class, small group, or pair work), and the learning environment (e.g. conventional classroom, community class, or outside the classroom) of a task. In a communicative task, both the learning mode and the environment should promote learner-centeredness, meaning learners are involved in learning through doing or using (Song, 2009).

\section{The Study ConteXt}

This study was initially an inspiration of curriculum change at the classroom level turned into a research project. As a new hire and the only full-time instructor in the Chinese as a minor program in a state university in Utah, besides teaching, my job was to evaluate the current program and make necessary changes to ensure that the program curriculum was aligned with the current trends of foreign language teaching. The first step I took to evaluate the current program was to read the syllabi in the previous years. After reading these, I found that there seemed to be inconsistency in terms of the teaching approach underlined between the course objectives and the course evaluations in the syllabi. Table 1 illustrates that the course objectives in the second-semester, first-year Chinese language course syllabus advocated the CLT approaches.

TABLE 1.

PREVIOUS COURSE SYLLABUS FOR CHIN 1020

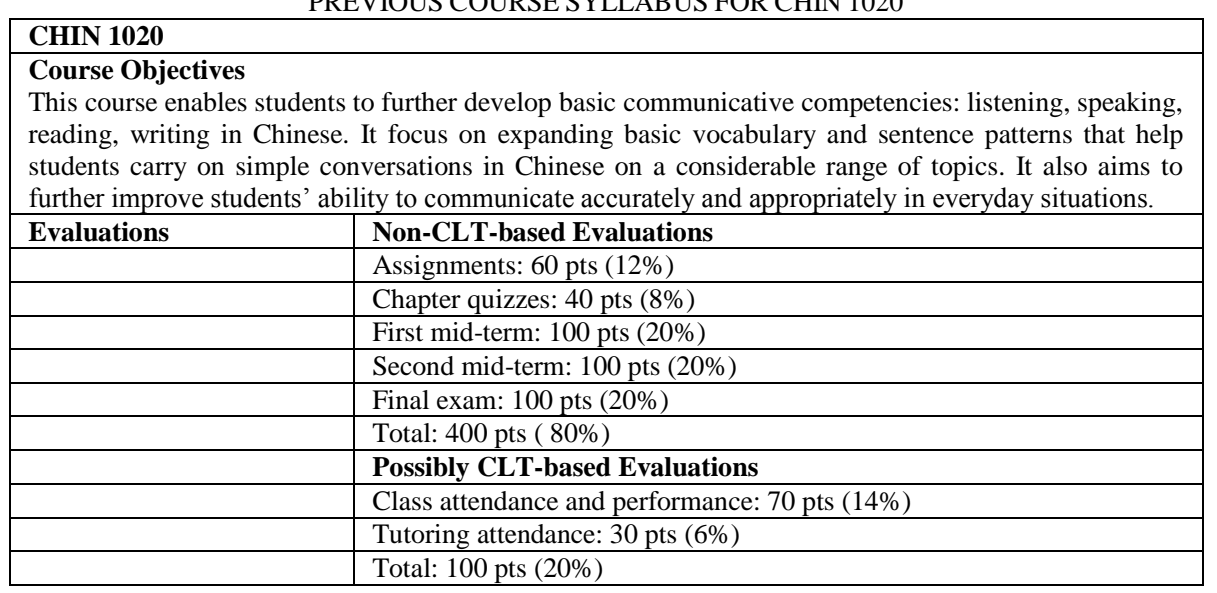

The learning goals stated in the objectives such as "communicate accurately and appropriately", "help students carry on simple conversations in Chinese", and "develop basic communicative competencies" all implied the implementation of the CLT in the class. However, the evaluation section of the syllabus shows that the grading system did not support the CLT objectives, but had the characteristic of a test-based curriculum. For instance, the homework assignments, quizzes, and exams accounted for $80 \%$ of the final grade while only $20 \%$ of the evaluations such as class performance and tutoring were possibly CLT-based.

After evaluating the syllabus from the previous year, I decided to decrease the percentage accounted for the paperand-pencil based homework assignments and tests to $50 \%$ and add newly designed CLT-based projects including a video-making project (10\%), a blog project (10\%), a storybook-making project (10\%), weekly Chinese-English language partner meetings (10\%), and Chinese New Year show (10\%) to 50\%. In this study, I only focused on the discussion of the three projects: the video-making, the blog, and the storybook-making projects, due to lack of consent from people who were not students in the Chinese class, but were involved in the language partner meetings and Chinese New Year show.

\section{METHOD}

A total of 15 students, six males and nine females, in the second-semester, first-year Chinese language class participated in the semester-long study. All of the participants were identified as true beginners, who had not studied Chinese in a classroom setting, home community, or in a study abroad context prior to their enrollment in the Chinese program under study. All participants in the study were non-heritage learners, whose parents were not of Chinese origin. Research instruments utilized to gather data included sample work of the participants' projects, project feedback forms, 
and two one-hour focus interviews with eight participants. All data were gathered toward the end of the semester after the participants had enough time to receive language input for the projects, complete the projects, and reflect on the projects. I use the participants' sample work to illustrate the characteristics of each of the three CLT-based projects and the level of the participants' success in gaining language knowledge through doing the projects. In regard to the data from the student project feedback forms and the focus group interviews, the schemes emerged in them were coded into different categories for discussion and a better understanding of the participants' reactions to do the projects.

\section{The Processes of Designing AND EXECUTING THE CLT-BASED PROJECTS}

I used Nunan's (1989) framework for analyzing communicative tasks as the guide when I designed the CLT-based projects. In the following tables and paragraphs, I list the task components which illustrate communicative characteristics of each of the projects followed by brief descriptions of how they were carried out as class projects. Finally, I use the participants' sample work to illustrate and discuss their language gains by doing the projects.

A. CTL-based Project 1: Blog Project

TABLE 2.

TASK COMPONENTS OF THE BLOG PROJECT

\begin{tabular}{|l|}
\hline Blog Project \\
\hline Goals: \\
(1) Discuss five topics on your blog, upon which the class touched \\
(2) Communicate effectively with bloggers from the Chinese class and from Taiwan \\
\hline Input: Prompt questions \\
\hline Activities: \\
(1) Use the prompt questions to help organize a short paragraph of at least 50 characters on your blog \\
(2) Respond to bloggers, who write comments on your blog entries. \\
(3) Visit your classmates' blogs and write comments regarding their blog entries. \\
\hline Learner roles: Blogger \\
\hline Teacher roles: Monitor, facilitator \\
\hline Settings: Individual/outside the classroom on the Internet \\
\hline
\end{tabular}

The blog project was a collaborative project with a class of undergraduate students who majored in Teaching Chinese as a second language in a university in Taiwan. The Taiwanese students were trained to respond in appropriate ways to Chinese language beginners. The Taiwanese students' responses to the participants were seen as a model of authentic forms of communication in the target language. The blog project was a ten-week activity in which every two weeks the participants were required to write a blog entry to respond to a set of prompt questions on a topic familiar to them, reply to comments from their classmates or the Taiwanese students posted below their blog entry, and post comments on their classmates' blogs. The purpose of this project was to stimulate authentic communication among the participants themselves and with the native speakers in Taiwan using vocabulary and grammar gained in class. The five topics discussed on the participants' blogs were (1)introducing yourself, (2)what do you like to wear?, (3)my daily schedule, (4)my house, and (5)my study, all of which were discussed in the textbook and in class prior to the beginning of the blog project. In the project, I acted as a monitor and facilitator overlooking the participants' language production. For example, when I identified a common language error which many participants made on their blogs, I would design an activity on the linguistic point without explicitly saying, "Many of you made this type of mistakes on your blogs!". The participants usually would discover that they made a mistake after the review activity and simply correct their language errors on the blog.

The paragraph listed below is a participant's sample work on the topic of "my daily schedule". It shows that the participant was able to loosely organize a short paragraph to describe her daily schedule with only minor grammar errors.

我的孩子八点去学校。我收拾我的客厅和厨房。我做 laundry, 我的孩子有很多很多衣服! 我做中文作业。 我也 take a nap 因为晚上我工作。I go to bed 一点-二点 am. 我三点半上课。我很忙，你呢？你每天几点起床？

Translation: [My children go to school at 8 o'clock. I clean up my living room and kitchen. I do laundry, my children have lots of clothes! I do Chinese homework. I also take a nap because I work at night. I go to bed at 1-2 am. I go to class at 3:30. I am very busy, and you? What time do you wake up?]

Initially the participant's writing about daily schedule was influenced by her native language, English, in terms of the placement of the time words. In English, descriptions of actions go before time words wile in Chinese time words are placed before actions. For example, the sentence, "My children go to school at 8 o'clock" is considered correct in English and the sentence "My children at 8 o'clock go to school" is accurate in Chinese. After reading the participant's and other students' blog entries on the topic of daily schedule, I found that the time word misplacement errors were very common. Hence, I reviewed the grammar pattern in class and the participant edited most time word mistakes except the sentence, "I go to bed 一点- 二点 am" (I go to bed at 1-2 am), which still uses English grammar. Another language feature of the participant is that she sometimes used her L1 as support to avoid communication breakdown, a useful strategy for language learners in real communication, which is identified as a kind of compensation language learning strategy by Oxford (1990). The L1 usage also gave a hint to the Taiwanese student who responded to the participant that 
the participant probably needed language assistance. The following response from the Taiwanese student illustrated that the correspondences had dual functions of language teaching/learning and real communication.

你要照顾孩子、洗衣服(做 laundry)、煮饭(to cook), 还要工作, 又要上课, 事情真的很多!

Translation: [You need to take care of the kids, do laundry, cook, work, and go to class. You have lots of things to do!]

First, the responder expressed his or her empathy on the participant's busy life at the end of the paragraph, which signified a form of real communication. Second, the responder attempted to implicitly correct the participant's language error by listing both incorrect and correct ways of saying a word side by side in the reply. For instance, the participant wrote "做 laundry", which means "do laundry" in English. However, in Chinese the accurate expression is "洗衣服", literally means, "wash clothes". The responder wrote "洗衣服 (wash clothes)" followed by "做 laundry (do laundry)" in parentheses so that the participant would learn how to write it the correct way in Chinese.

Even though the participants were required to reply to only two people for each blog entry, but the initially simulated real-life project turned into real-life communication among the participants and with the Taiwanese students. As a result, many of the participants responded more times to more people than the project required.

B. CTL-based Project 2: Storybook-making Project

TABLE 3 .

TASK COMPONENTS OF THE STORYBOOK-MAKING PROJECT

\begin{tabular}{|l|}
\hline Storybook Making Project \\
\hline Goals: \\
(1) Comprehend authentic reading materials (e.g. storybook) \\
(2) Make authentic reading materials in the target language \\
\hline Input: Storybooks for Children \\
\hline Activities: \\
(1) Read and comprehend the storybook assigned \\
(2) Make your own storybook \\
\hline Learner roles: Storybook reader and summarizer, Storybook writer and editor \\
\hline Teacher roles: Facilitator \\
\hline Settings: Individual/in and outside the classroom \\
\hline
\end{tabular}

The storybook-making project consisted of several steps. First, I modeled how to read aloud and comprehend a storybook using one of the books in the book series that the participants would later be assigned to read. In particular, I offered character decoding strategies the participants could use when they encountered characters that look familiar, but couldn't remember the meanings of them. I also suggested strategies such as using a dictionary and asking their Chinese speaking language partners or other native speakers when they simply did not comprehend certain words. Once they were equipped with strategies to read authentic materials, each of them was assigned a book in the I Can Read Myself book series published by Greenfield Educational Center in Taiwan. The book series consist of 48 books relevant for three to seven-year-old Chinese native readers. The books are pattern books which use repetitive language, scenes and sequences that allow early readers to predict what the sentences are going to say. I deemed that the books were relevant for my students as pattern books offer increasing enjoyment and help develop language beginners' vocabulary (Peregoy $\&$ Boyle, 2001). After reading the book assigned, the participants were to write a book report, which included writing a brief summary of the story, identifying the repetitive language patterns used in the story, listing vocabulary words learned, and making meaningful sentences using the newly learned words. Next, the participants were to make their own pattern storybook in the target language. The justification for the project was based on the CLT concept that once the participants had relevant input from the interaction with authentic materials, they were expected to progressively become independent learners who were capable of making authentic language production. I served as a facilitator throughout the storybook-making process in and outside the classroom whenever the students had questions or needed assistance on brainstorming ideas for their stories. Finally, the participants needed to read aloud their own books in class as if they were telling a story to children.

The participants' self-made pattern books were of good quality. First, each book had its own plots and humor which made the book interesting to read. Second, the language used in the book extended beyond the language knowledge they learned in class. In the interviews, the participants explained that they sometimes used a dictionary or asked a native speaker if they wanted to write words or sentences they did not know how to write. The good quality of the learners' end-projects suggest that when the learners did simulated real-world tasks, they were better able to think of the language task as a real-life task and went beyond the minimum project requirements.

The following images illustrate the first few pages of a participant's self-made storybook. 


\section{石頭}<smiles>[10BH]</smiles>

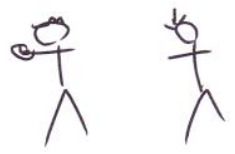

這是我的石頭。

Image 4. This is my rock

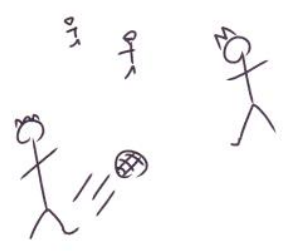

他們踢足球。

Image 7. They play soccer

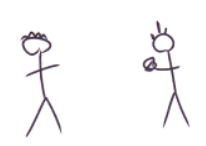

那是我的石頭。

Image 2. That is my rock

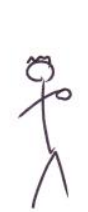

他看三個人。

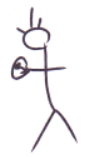

這是你的石頭嗎?
Image 3 . Is this your rock?

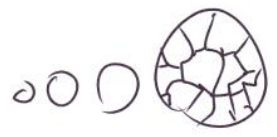

\section{他的石頭變成球。}

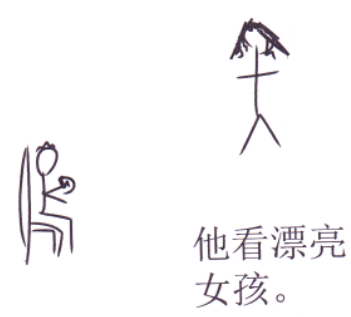

Image 8 . He sees a pretty girl
Image 6. His rock becomes a ball

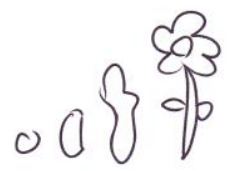

他的石頭變成花。

Image 9. His rock becomes a flower

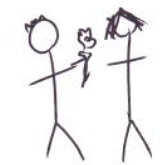

他給漂亮女孩花。

Image $10 . \mathrm{He}$ gives the pretty girl the flower

The participant started with the story using a basic grammar function, the demonstratives (e.g. this or that), to show where the main object in the story, the rock, is in relation to the speaker (See Images 1 to 4 ). The pages (See Images 5 to 10) following the use of the demonstratives are a repetitive pattern of three kinds: (1) He sees..., (2) His rock becomes...., and (3) a description of what people do with the rock in its new form. While the participant read the story to the class, his peers seemed to enjoy the book and applauded him for his creative story plots.

C. CTL-based Project 3: Video-making Project 
TABLE 4.

TASK COMPONENTS OF THE VIDEO-MAKING PROJECT

\begin{tabular}{|l|}
\hline Video-Making Project \\
\hline Goals: Use newly learned language knowledge in simulated real-world situations \\
\hline Input: Linguistic knowledge learned in class \\
\hline Activities: \\
(1) Write a three to four minute skit or a song \\
(2) Acting out the skit and make a video or sing the song and make a music video \\
\hline Learner roles: Skit/song writer, actor/singer, video director, good team member \\
\hline Teacher roles: Facilitator, confidence booster \\
\hline Settings: small groups of two to four people/in and outside the classroom \\
\hline
\end{tabular}

The video-making project was the participants' final project, which was designed as a way to evaluate the participants' linguistic gain and ability to apply the newly learned linguistic knowledge of the year in simulated real-life communication at the end point of the second semester of Chinese language study. Earlier in the semester, I have modeled how to write short skits and songs and asked the participants to try the same in class activities. Hence, the participants were familiar with the task process. The difference in the final project was that this time the participants were expected to become independent learners who used their own creativity in designing the topics and scenes of their skit/song and that the duration requirement of the skit/song was longer than the ones practiced in class. Moreover, the participants were asked to video-tape their end-products which they would share with other class members on Blackboard, a course management website where the participants could post their video clips and comments. Two weeks after announcing the final project, I held a Q\&A session in which the participants brought up any questions they had about the project. The participants brought with them their working products and had both language and project requirement-related questions for me. The session was useful to both the participants and I as I was able to clarify any misunderstandings, facilitate with the participants' language production for the project, and gave positive comments about their working products to boost their confidence level. As a project facilitator, I told the participants that they were always welcome to visit me about their project before the project deadline.

The end results of the video-making project were pleasantly surprising to me. Three groups of the participants decided to enter their music videos for a national online Chinese language student singing contest held by a book publishing company. Entering the contest voluntarily showed that the participants were to some degree confident about their end-products even though they only had learned Chinese for less than a year. Moreover, it shows that by creating a simulated real-life task, the learners went out of their ways to connect their project with a real-world task. As a result, two of the three groups in the study which entered to compete with 173 other singing groups in the nation were picked as two of the top ten music videos by three professional judges in the areas of Chinese language learning and Chinese pop-song singing. The positive results in the real-life task strongly encouraged the groups to continue with Chinese language study. In regard to the participants' quality of language production for the project, the following lyrics written by one of the singing groups illustrates that the participants attempted to use grammar patterns and vocabulary introduced in class.

請來吃我的中國菜。[Please come to eat my Chinese food]

請來喝我的白葡萄酒。[Please come to drink my white grape wine]

我的手會做好吃的食物。[My hands make good food]

我的手對你來説是完美的。[My hands are perfect to you]

In the first two lines, the participants used the same structure, "please come to + action phrase" with vocabulary words such as "to drink", "to eat", "Chinese food", and "white grape wine" to make invitations. The last two lines are descriptions of what "my hands" can do and are perceived to "you". Most of the words used in the lyrics were taught in class; nonetheless, I spotted a few new vocabulary items. The participants said that they asked Chinese native friends to help them with words they wanted to express, but didn't know in Chinese. The lyrics writing process created the opportunity for the learners to test out the language knowledge gained in class and encouraged them to be in contact with native speakers for both language learning and real communication purposes.

\section{STUdents' REActions to the CLT-Based PROJeCts}

The CLT-based projects were well-received in general by the participants with suggestions for minor modifications to make the projects more suitable for their needs in the particular learning context under study. The next few paragraphs discuss the schemes emerged from the participants' feedback forms and the focus group interviews.

\section{A. The Projects Were Fun!}

The projects were simply interesting to do for the participants. Many participants used the word "fun" to describe what they felt about doing the projects:

I liked all the projects. They were fun! (Feedback form 11)

It was good practice and fun to get to know someone from Taiwan (Feedback form 2).

We totally thought it was fun. I don't know much about music, so it's like I can't do this unless I have someone like Dave. I would say the video was definitely of the three projects the most fun (Interviewee 8). 


\section{B. The Projects Reinforced Authentic Communication}

A purpose of the CLT-based projects was to offer the participants opportunities to use Chinese in an authentic social context which created variety of social interactions and relationships. A participant expressed his like to interact with other bloggers:

My favorite part was the interaction when you were like somebody was commenting on what you said and you were commenting back on what they said. You feel like you are communicating as oppose to writing paragraphs, writing paragraphs is so single sided. You can just do it by yourself. The communication part was great (Interviewee 8).

Other participants stressed their likes of authenticity in terms of the project materials and communication:

I thought the blog project was great! It gave me a chance to write stuff like the email assignments in our workbook except I could write about ME in real life! :) (Feedback form 14)

I really enjoyed being in contact with students across the globe from me (Feedback form 9).

It was fun to see real books (Feedback form 7).

My son still goes around the house singing the song we made (Feedback form 10).

The last comment from Feedback form 10 illustrates that the projects not only encouraged the participants to communicate in the target language with their peers and native speakers, but also brought communication in the target language to their family members, creating more opportunity for the participants to practice the language.

\section{The Projects Fostered Student Autonomy and Helped Express Individual Personality}

The designs of the projects allowed certain degree of flexibility for the participants to decide on what kind of end products they wanted, which fostered student autonomy. A participant commented in her feedback form:

I like the video project because we decide what we want to present. (Feedback form 4)

The participants appreciated the flexibility, which allowed them not only to feel the independence as capable learners, but also to show their peers who they were through their end-products. The interviewees expressed:

I like the blog thing cause it kind of helped show my personality. I would like to do it more (Interviewee 2).

My favorite was the final project. I love being able to work with a great partner together to come up with a personalized and toned skit to let our personalities come through the Chinese instead of just a bunch of rote sentences (Interviewee 7).

According to Breen (as cited in Song, 2009, p.86), projects which assist learners to demonstrate their independence and personalities, advocate "achievement orientation, which learners adopt when they perceive that tasks relate closely to their personal needs". The participants took the active learner role in the projects and did not feel that they did the tasks simply because they had to do it for the class.

\section{The Projects Stimulated Creativity and Promoted Independent Language Learning}

The participants deemed that they became creative and independent language learners. An interviewee commented:

I had fun coming up with the idea for the story. You get to be creative and in order to say what you want you have to learn new words. So the grammar and vocabulary you are adding to yourself and you are expressing that...In a way you are teaching yourself and the people to read it. So it's kind of cool (Interviewee 3).

The main purpose of a communicative task is that "learners should use the language they know in order to get meaning across as effectively as possible" (Ma, 2009, p. 53). In order to get meaning across in the project assignments, the participants used different language learning strategies:

It (writing blog entries) made me think not just one little sentence, but a whole thought process of how I would organize a paragraph (Interviewee 5).

I have to guess meaning and get as much as I can (Feedback form 13).

I read it (a blog response), and when I didn't know, I used an online dictionary (Feedback form 2).

\section{E. The Projects Helped Develop All Four Language Skills}

The projects provided opportunities for the participants to practice listening, speaking, reading, and writing skills in integrated ways, which is a characteristic of a communicative task. As a result, the participants expressed that the Chinese they learned through doing the projects would stick in their heads forever:

I remember every single word I learned and wrote in my storybook. How do you forget that! You even draw pictures with it. You are making the visual. You are writing physically. You are drawing physically. It's like totally lives in your head (Interviewee 4).

Everything we have done that's involved drawing something has been helpful for me. You are saying the words in your head when you are drawing (Interview 6).

A lot of words became comfortable for me during the (video-making) process, like 誰 [who], 在 [in], 手[hand], I will never forget these words (Interviewee 2).

\section{RECOMMENDATIONS FOR MODIFICATIONS}

The participants mentioned two recommendations for future CLT-based project modifications. The first recommendation, investigating students' level of technology capability, solely applies to projects involving the use of 
technology, while the second recommendation, emphasizing more on individual learner differences, can be applied to all CLT-based projects.

\section{A. Investigating Students' Level of Technology Capability}

Several participants ran into technical problems when they started the blog project. Even though I demonstrated how to create and write on a blog, and posted the instruction on the class website, a few participants still encountered technical difficulties of different kinds. A participant said:

It was difficult for the fact.....because...the learning of technology. I posted the thing on the wrong pages cause I didn't really know what I was doing. I have never done it before, and also just getting the computer cause I have always had to come to the computer lab to do it cause my computer at home does not have the Asian language input files installed (Interviewee 3).

It seems that for future CLT-based technology projects such as the blog project, a better preparation plan of technology use should be set up to ensure that learners are technically ready to do the projects. It was evident that once technology issues were solved, the participants were able to enjoy doing the project:

At first I didn't want to write in a blog because I have never had one before but once I figured out how to do it, writing in a blog become more fun (Feedback form 1).

\section{B. Emphasizing More on Individual Learner Differences}

A few participants expressed their desire of "doing their own thing" for CLT-based projects. Even though the three projects in the study allowed certain degree of flexibility for learners such as deciding on a topic for their own storybook and skit/song, some of the participants craved for more flexibility in order to fit their learning styles and allow more space for their creativity. In regard to the video-making project, a participant said:

I think the only thing I would change is just that like we liked that we could do a big group thing you know. Some people like doing it in two people, but I think it's nice if there is a flexibility in that. If the purpose of the project is to help learn in a creative way or from some source. If you just like say this is the purpose of the whole thing, this is what we normally do, but I will let you go off your own way. Like that way, you know, can still get the purpose out of it, but do their own thing (Interviewee 8).

Another participant added her opinion about having more flexibility regarding the blog project:

It is good to have all the prompt questions, but it would also be nice to have a subject and then just have the freedom to write on that subject. You know like "talk about clothes" and we are free to do whatever we want as long as we talk about clothes. It can do bad things like make people use only the language they know and not learn more stuff, but it also could open up to learning stuff you wanna say that you haven't learned (Interviewee 6).

However, a participant did not think that opening up more flexibility would help with his learning. He expressed:

I think a few students would really open up their creativity that way and go above and beyond. I think most students, certainly myself, if you just said, "talk about clothes", I would probably not be nearly as motivated to really try and find out how to say the things that are more difficult things to say that you asked. So I liked that you asked a lot of very specific questions (Interviewee 7).

The opposite opinions of the participants in regard to project flexibility suggest that instructors need to take into account the individual learner differences and design projects which can best fit all learners' needs to maximize their learning. Giving optional project requirements may be one way to cope with learners' different learning styles in the case under study.

\section{SUMMARY}

In answering the question about the participants' linguistic gains in doing the projects, the good quality of the participants' works have demonstrated that the participants used different strategies to exceed their current language level in attempts to convey meanings in the target language. According to Quinn (1984), a criterion of success in CLT is "to have students communicate effectively and in a manner appropriate to the context they are working in" (p. 62). The three projects discussed in the study have achieved the aim of communicating effectively and appropriately in a given context. For instance, the participants were able to write short paragraphs of different topics and replied to their peers' comments on the blogs. The participants' self-made videos successfully expressed their thoughts and personalities. Some of the videos were approved by Chinese native speaking judges in the singing contest as the best videos made by language students of Chinese in the nation. The storybook project was also a success in which the participants enjoyed and applauded for each other's creativity and language accomplishment.

Moreover, the participants responded positively about the three CLT-based projects. In short, the participants expressed that the projects reinforced authentic communication, fostered student autonomy, helped express personalities, stimulated creativity, promoted independent language learning, and helped developed all four language skills. Most importantly, the projects were fun for the participants. I believe that these positive language learning phenomenon gained by the participants were only possible through doing the CLT-based projects, which required the learners to go through the learning process of comprehending, manipulating, producing, and interacting in the target language (Nunan, 1989). Nonetheless, there is room for improvement in designing the CLT-based projects. One key point in making 
improvements according to the participants is to learn about students' needs in a particular teaching context. In the case of my participants, some of them needed more technical training than I expected in order to complete the blog project smoothly. In addition, I underestimated some of my participants' level of creativity and did not give them enough room to fully display their high level of creativity. CLT principles advocate practice of teaching to specific needs (Song, 2009). Nunan (1988) suggests that instructors collect information about learner needs before designing the curriculum because the aim of CLT-based curriculum is to cover what the learner needs and see as important.

\section{REFERENCES}

[1] Bax, S. (2003). The end of CLT: A context approach to language teaching. ELT Journal, 57(3), 278-287.

[2] Canale, M.\& Swain, M. (1980). Theoretical bases of communicative approaches to second language teaching and testing. Applied Linguistics, 1, 1-47.

[3] Chomsky, N. (1965). Aspects of the theory of syntax. Cambridge, MA: MIT Press.

[4] Feryok, A. (2008). An Armenian English language teacher's practical theory of communicative language teaching. System, 36, 227-240.

[5] Hiep, P. H. (2007). Communicative language teaching: Unity within diversity. ELT Journal 61(3), 193-201.

[6] Holliday, A. (1994). The house of TESEP and the communicative approach: The special needs of state English language education. ELT Journal, 48(1), 3-11.

[7] Hu, G. (2005). CLT is best for China - an untenable absolutist claim. ELT Journal, 59(1), 65-68.

[8] Hymes, D. (1987). Communicative competence. In U. Ammon, N. Dittmar \& K. J. Mattheier, (Eds.), Sociolinguistics: An international handbook of the science of language and society (pp. 219-229). Berlin: Walter de Gruyter.

[9] Larsen-Freeman, D. (2000). On the appropriateness of language teaching methods. In J. Shaw, D. Lubeska \& M. Noullet (Eds.). Language and development: Partnership and interaction. Bangkok: Asian Institute of Technology.

[10] Leung,C. (2005). Convival Communication: recontextualizing communicative competence. International Journal of Applied Linguistics, 15(2), 119-143.

[11] Li, X., \& Hedebouw, E. (2009). The use of literature circles in CFL teaching: "太棒了!". Journal of the Chinese Language Teachers Association, 44(3), 43-72.

[12] Liao, X. (2003). Chinese secondary school teachers' attitudes towards communicative language teaching and their classroom practices. Retrieved from ProQuest These and Dissertations database (AAT No. 3134003).

[13] Liao, X. (2004). The need for communicative language teaching in China. ELT Journal 58(3), 270-273.

[14] Ma, Q. (2009). Key elements in conducting communicative approach to language teaching. Canadian Social Science,5(2), 4655.

[15] Nunan, D. (1988). The learner-centred curriculum. New York: Cambridge University Press.

[16] Nunan, D. (1989). Designing tasks for the communicative classroom. Cambridge: Cambridge University Press.

[17] Oxford, R. (1990). Language learning strategies: What every teacher should know. New York: Newbury House Publishers.

[18] Peregoy, S. F., \& Boyle, O. F. (2001). Reading, writing, \& learning in ESL. New York: Longman.

[19] Quinn, T. (1984). Functional approaches in language pedagogy. Annual Review of Applied Linguistics, 5, 60-80.

[20] Saville-Troike, M. (2003). The ethnography of communication. Malden: Blackwell Publishing.

[21] Schiffrin, D. (1994). Approaches to discourse. Oxford: Blackwell.

[22] Song, Y. (2009). How can Chinese English teachers meet the challenge of creating a learner-centered, communicative, intercultural classroom to achieve optimal student learning outcomes? Canadian Social Science, 5(6), 81-91.

Ko-Yin Sung was born in Kaohsiung, Taiwan in 1977. She completed her PhD in 2009 in Culture, Literacy \& Language from the University of Texas at San Antonio.

She is Assistant Professor of Chinese in the Department of Languages, Philosophy \& Speech Communication in the College of Humanities, Arts and Social Sciences at Utah State University. Her research interests include Chinese language teaching and learning, language learning strategies, and technology-assisted language learning. 